\title{
'Florida Whitewater' Caladium - A University of Florida Cultivar 1
}

\section{G.J. Wilfert, B.K. Harbaugh, and B.D. Miranda ${ }^{2}$}

Caladiums [Caladium bicolor (Ait.) Vent., syn. Caladium xhortulanum Birdsey], grown for their colorful foliage, are members of the aroid family (Araceae Juss.) native to tropical America (Croat, 1979). Although their native habitat largely consists of dense, moist forests with heavy shade, many of the cultivars grown today retain their bright color in full sun (Bell and Wilfret, 1998). Demand for caladiums is increasing because of their diversity in leaf color and shape, adaptability to various light conditions, and relatively low maintenance requirements (Harbaugh and Tjia, 1985).

As much as $90 \%$ of the caladium tubers produced are used by the container plant industry primarily in 10 - and $15-\mathrm{cm}$ containers (D. Bates, personal communication). Many popular cultivars require excision of dominant buds (de-eyeing) on the tuber in order to produce an attractive container-grown plant. Bud excision eliminates apical dominance, resulting in greater leaf production and reduced plant height (Evans et al., 1992), but is a costly, labor-intensive procedure. 'Florida Whitewater' (Fig. 1) is a highly compact plant producing numerous, uniquely narrow, lanceolate leaves without requiring bud excision. Excellent sun tolerance enhances its potential for use in the landscape as a border or in combination with caladium cultivars with differing foliar and growth habit characteristics.

\section{Orgin}

'Florida Whitewater', derived from a cross between the popular caladium cultivars 'White Wing' and 'White Queen', initially was evaluated in 1985 as GC85-338. Ancestry of both parents is unknown. 'White Wing', a white lance-leaf cultivar, was selected as the female parent because of its excellent sun tolerance and ability to produce many leaves on strong upright petioles. 'White Queen', a creamy-white heart-shaped leaf cultivar, was selected because of its attractive foliage with green netted venation and red primary veins. Tubers were propagated on fumigated Eaugallie fine sandy soils at the Gulf Coast Research and Education Center (REC) in Bradenton, FL, and were hot-water treated for nematode control (Rhodes, 1964).

1. This document is ENH964, one of a series of the Environmental Horticulture Department, Florida Cooperative Extension Service, Institute of Food and Agricultural Sciences, University of Florida. Original publication date September 25, 2003. Visit the EDIS Web Site at http://edis.ifas.ufl.edu.

2. G.J. Wilfert, professor, Department of Environmental Horticulture, Gulf Coast Research and Education Center; B.K. Harbaugh, professor, Department of Environmental Horticulture, Gulf Coast Research and Education Center; and B.D. Miranda, post doctoral researcher, Department of Environmental Horticulture, Gulf Coast Research and Education Center, Cooperative Extension Service, IFAS, University of Florida, Gainesville, FL 32611.

The Institute of Food and Agricultural Sciences (IFAS) is an Equal Employment Opportunity - Affirmative Action Employer authorized to provide research, educational information and other services only to individuals and institutions that function without regard to race, creed, color, religion, age, disability, sex, sexual orientation, marital status, national origin, political opinions or affiliations. For information on obtaining other extension publications, contact your county Cooperative Extension Service office. Florida Cooperative Extension Service / Institute of Food and Agricultural Sciences / University of Florida / Larry R. Arrington, Interim Dean 


\section{Description}

Descriptions of color (e.g. RHS 200C) for plant parts are based on comparison with the Royal Horticultural Society's color chart (Royal Horticultural Society, 1986).

'Florida Whitewater' (Fig. 1) plants grown for 7 months were $29-37 \mathrm{~cm}$ tall. Jumbo tubers are highly segmented, 6.4-8.9 $\mathrm{cm}$ in diameter, bearing 10-12 dominant buds. Tuber surfaces are brown (RHS 200C) with the cortical area yellow (RSH 8B). Leaves are lanceolate, $18-22 \mathrm{~cm}$ long and $5-9 \mathrm{~cm}$ wide, with green (RHS 139C) penniform venation. The upper surface has dark green margins (RHS 137A) up to $5 \mathrm{~mm}$ wide. A thin, greyed-purple line (RHS 185A), $1 \mathrm{~mm}$ wide, is present on the basal leaf collar at the petiole apex. Interveinal areas of the leaf center are white (RHS 155C) and slightly undulated. Irregular green-white (RHS 157A) mottling parallels the margins. The undersurface has greyed-green (RHS 191B) margins and veins with white (RHS $155 \mathrm{CF}$ ) interveinal regions at the center. Petioles are 2-5 $\mathrm{mm}$ in diameter and a densely speckled brown (RHS 200B).

Plants used for describing color were grown in $15-\mathrm{cm}$ containers in a $40 \%$ shaded greenhouse from 2.54-cm diameter tubers. Tubers of 'Florida Whitewater' do not require bud excision for optimum performance as container plants. Petioles tend to cascade as leaves enlarge, creating a whitewater effect.

\section{Performance}

'Florida Whitewater' was evaluated for tuber production at the Gulf Coast REC-Bradenton, FL during 1996, 1998, 1999, and 2000. The soil was an Eaugallie fine sand with organic matter and a $\mathrm{pH}$ of 6.2. Plants were grown in a plastic-mulched, raised-bed system maintaining a constant water table with seep irrigation (Geraldson et al., 1965). Ground beds were fumigated 3 weeks before planting with a mixture of $67 \%$ methyl bromide and $33 \%$ chloropicrin (by volume) at $392 \mathrm{kgha}^{-1}$. The beds were $91 \mathrm{~cm}$ side and $20 \mathrm{~cm}$ high with $2.54-\mathrm{cm}$ caladium seed pieces planted $15 \mathrm{~cm}$ apart in 3 rows spaced $15 \mathrm{~cm}$ apart. Osmocote $18 \mathrm{~N}-2.6 \mathrm{P}-10 \mathrm{~K} 8-9$ month controlled-release fertilizer (Osmocote

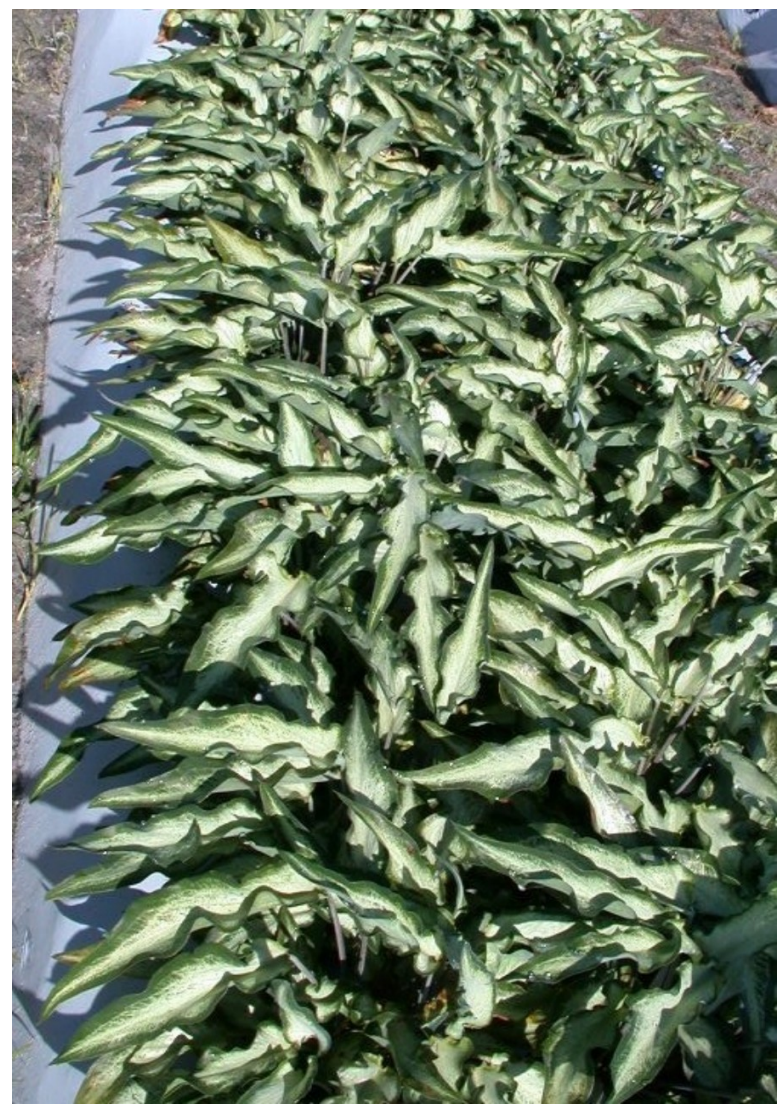

Figure 1. 'Florida Whitewater' is a highly compact plant with white strap-leaves ideal for hanging baskets or for shade or full sun landscapes.

18-6-12, Scotts Co., Marysville, OH) was applied to the bed surface at the time of fumigation with $\mathrm{N}$ at $336 \mathrm{kgha}^{-1}$.

Plots were organized in a randomized complete-block design consisting of 3 replications. An analysis of variance combined over years was conducted in order to compare the performance of 'Florida Whitewater' to several commercial lance-leaf cultivars (Tables 1 and 2).

Marketable tuber weight of 'Florida Whitewater' was lower than 'White Wing' and 'Jackie Suthers' but much higher than 'Pink Gem'. However, the production index was similar for 'Florida Whitewater', 'White Wing' and 'Jackie Suthers' and lowest for 'Pink Gem'. The production index reflects the crop value as prices change from year to year or grower to grower, but the differences between grades usually remain constant (Harbaugh and Overman, 1983). The marketable number of tubers produced by 'Florida Whitewater' was higher than 'White Wing' and 'Pink Gem', and similar to 'Jackie Suthers'. 
Although 'Florida Whitewater' produced a lower percentage of mammoth tubers than the major white-lance cultivars 'White Wing' and 'Jackie Suthers', it amassed a favorable production index value by producing a high number of marketable tubers well distributed in valuable grades.

Landscape performance of cultivars grown under full-sun conditions was evaluated in 1996, 1998, and 1999 (Table 3) on the same plots used for evaluating tuber production. Plant height, leaf number, and foliar dimensions were recorded months after planting. 'Florida Whitewater' plants were much shorter than either 'White Wing' or 'Jackie Suthers' and were similar to 'Pink Gem'. 'Florida Whitewater' also produced a superior number of leaves that were narrower than the commercial cultivars and exhibited excellent sun tolerance. Short plants in combination with numerous leaves create a very desirable compact appearance.

'Florida Whitewater' tubers were forced in 10-cm containers and growth compared to commercial cultivars in 1998 (Table 4). The root medium contained 3 sedge peat : 1-1/2 coarse horticultural vermiculite : 1 sand (by volume) amended with (in $\mathrm{kgm}^{-3}$ ) 3 dolomitic lime, 3 calcitic lime, 3 single superphosphate, 0.6 micronutrient mixture (Micromax, Scotts Co.), and 1.8 14N-6.1P-11.6K 3-4 month controlled-release fertilizer (Osmocote 14-14-14, Scotts Co.). Plants were grown in a glasshouse with $40 \%$ light exclusion during the summer in Bradenton, FL. Average daily temperatures were $32 \mathrm{C}^{\circ}$ day $/ 21 \mathrm{C}^{\circ}$ night during the experiment. Plant height, number of leaves, and foliar characteristics were recorded 7 weeks after planting. A completely randomized design consisting of 6 single plant experimental units was used.

Leaf production of 'Florida Whitewater' was superior to 'White Wing' and 'Jackie Suthers', as was observed in landscape-grown plants under full-sun conditions (Table 3). Leaves were shorter and narrower for 'Florida Whitewater' compared with the white lance-leaf cultivars. 'Pink Gem' produced a similar number of wider leaves to 'Florida Whitewater' and leaf length was essentially the same. Plants of 'Florida Whitewater' were more compact than the commercial cultivars. Plant compactness and high leaf number without bud excision are desirable traits for caladium container producers as this facilitates the production for full, attractive containers.

'Florida Whitewater' is intended for forcing in containers of 10 - to $20-\mathrm{cm}$ diameter and for use in shady to full-sun locations in the landscape. Plant compactness suggests that 'Florida Whitewater' would make an attractive border planting. This new white lance-leaf cultivar offers advantages over both tuber and container producers. Although extensive research and evaluations have been performed on small acreages of this cultivar, tuber producers are encouraged to plant only limited quantities of 'Florida Whitewater' until they have gained experience in production. Standard postharvest treatment of tubers is recommended and preplant hot-water treatment of tubers is encouraged to prolong their life.

\section{Availabilty}

A patent has been applied for 'Florida Whitewater' by the Florida Agricultural Experiment Station and production of this cultivar is to be with a licensing agreement with the Florida Foundation Seed Producers, Inc., P.O. Box 309, Greenwood, FL 32443. Information on tuber availability and propagation agreements an be obtained from the Florida Foundation.

\section{Literature cited}

Bell, M.I. and G.J. Wilfert. 1998. Survey of caladium tuber production for acreage of cultivars grown. Proc. Fla. State Hort. Soc. 111:32-34.

Croat, T. 1979. The distribution of Acaceae, p. 291-308. In: K. Larson and L.B. Holm-Nielson (eds.). Tropical botany. Academic Press, New York.

Evans, M.R., G.J. Wilfret, and B.K. Harbaugh. 1992. Caladiums as potted and landscaped plants. IFAS, Univ. of Fla. Agr. Ext. Serv. Circ. 1060.

Geraldson, C.M., A.J. Overman, and J.P. Jones. 1965. Combination of high analysis fertilizers, plastic mulch and fumigation for tomato production 
on old agricultural land. Proc. Soil and Crop Sci. Soc.

Fla. 25:18-24.

Harbaugh, B.K. and B.O. Tjia. 1985.

Commercial forcing of caladiums. IFAS, Univ. of

Fla. Agr. Ext. Serv. Circ. 621.

Harbaugh, B.K. and A. J. Overman. 1983.

Evaluation of fertilizer types and rates on

Caladiumxhortulanum Birdsey Candidum tuber production in muck and sandy soil management

systems. Proc. Fla. State Hort. Soc. 96:250-254.

Rhodes, H.L. 1964. Effect of hot water

treatment of seed tubers and soil fumigation for control of root knot on yield of caladiums. Plant Dis. Rptr. 8:568-571.

Royal Horticultural Society. 1986. RHS Colour Chart. Royal Hort. Soc. London. 
Table 1. Tuber weights and the production index for caladium cultivars harvested in 1996, 1998, 1999, and 2000. Values presented are means of 3 replications with 30 propagules per $1.2-\mathrm{m}^{2}$ plot per year, averaged over 4 years.

\begin{tabular}{|c|c|c|c|c|c|}
\hline \multirow[b]{2}{*}{ Cultivars } & \multicolumn{4}{|c|}{$\underline{\text { Tuber wt }(\mathrm{g})}$} & \multirow{2}{*}{$\begin{array}{l}\text { Production } \\
\text { index }{ }^{y}\end{array}$} \\
\hline & Marketable & Seed & Total & Mean $^{2}$ & \\
\hline Florida Whitewater & 2516 & 192 & 2709 & 67 & 92 \\
\hline Jackie Suthers & 3261 & 116 & 3377 & 91 & 89 \\
\hline Pink Gem & 1474 & 151 & 1625 & 46 & 62 \\
\hline White Wing & 3170 & 99 & 3269 & 88 & 98 \\
\hline $\operatorname{LSD}(a=0.05)$ & 326 & 50 & 324 & 7 & 10 \\
\hline \multicolumn{6}{|c|}{$\begin{array}{l}{ }^{z} \text { Mean }=\text { Marketable weight } / \text { marketable number. } \\
{ }^{y} \text { The production index is an indicator of economic value of the crop calculated as } N(\text { No. } 2 s)+2 N \text { (No. } \\
1 s)+4 N(\text { Jumbo) }+6 N \text { (Mammoth) }+6 N \text { (Super Mammoth); where } N=\text { number of tubers in each grade }\end{array}$} \\
\hline
\end{tabular}

Table 2. Tuber grade distribution of caladium cultivars harvested in 1996, 1998, 1999, and 2000. Values presented are means of 3 replications of 30 propagules per $1.2-\mathrm{m}^{2}$ plot per year, averaged over 4 years.

\begin{tabular}{|c|c|c|c|c|c|c|}
\hline \multirow[b]{2}{*}{ Cultivars } & \multicolumn{5}{|c|}{ Marketable tubers by grade ${ }^{z}(\%)$} & \multirow[b]{2}{*}{$\begin{array}{l}\text { Marketable } \\
\text { tubers (no.) }\end{array}$} \\
\hline & $\begin{array}{c}\text { Super } \\
\text { Mammoth }\end{array}$ & Mammoth & Jumbo & No. 1 & No. 2 & \\
\hline Florida Whitewater & 0 & 3 & 24 & 47 & 25 & 39 \\
\hline Jackie Suthers & 1 & 7 & 18 & 41 & 33 & 37 \\
\hline Pink Gem & 0 & 1 & 11 & 45 & 44 & 34 \\
\hline White Wing & 0 & 8 & 30 & 44 & 18 & 36 \\
\hline $\operatorname{LSD}(a=0.05)$ & 1 & 3 & 5 & 8 & 8 & 3 \\
\hline
\end{tabular}


Table 3. Plant performance after 7 months for caladium cultivars grown in full sun from $2.5-\mathrm{cm}$ tubers in 1996, 1998, and 1999. Values presented are means of 3 replications with 3 plants measured per plot per year, averaged over 3 years.

\begin{tabular}{|lcccc|}
\hline \hline & & & \multicolumn{2}{c|}{ Leaf } \\
\cline { 5 - 5 } Cultivar & $\begin{array}{c}\text { Plant ht } \\
(\mathrm{cm})\end{array}$ & $\begin{array}{c}\text { Leaves } \\
(\text { no. })\end{array}$ & $\begin{array}{c}\text { Length } \\
(\mathrm{cm})\end{array}$ & $\begin{array}{c}\text { Width } \\
(\mathrm{cm})\end{array}$ \\
\hline Florida Whitewater & 33 & 24 & 20 & 7 \\
Jackie Suthers & 53 & 16 & 22 & 14 \\
Pink Gem & 32 & 17 & 17 & 11 \\
White Wing & 54 & 14 & 26 & 16 \\
LSD $(a=0.05)$ & 4 & 7 & 2 & 2 \\
\hline \hline
\end{tabular}

Table 4. Plant performance after 7 weeks for caladium cultivars grown from No. 1 tubers in 10-cm containers in a $40 \%$ shaded glasshouse, 1998. Values presented are means of 6 plants with 1 No. 1 ( $>3.8<6.4 \mathrm{~cm}$ diameter) intact tuber planted per container.

\begin{tabular}{|lcccc|}
\hline \hline & & & \multicolumn{2}{c|}{ Leaf } \\
\cline { 5 - 5 } Cultivar & $\begin{array}{c}\text { Plant ht } \\
(\mathrm{cm})\end{array}$ & $\begin{array}{c}\text { Leaves } \\
(\text { no. })\end{array}$ & $\begin{array}{c}\text { Length } \\
(\mathrm{cm})\end{array}$ & $\begin{array}{c}\text { Width } \\
(\mathrm{cm})\end{array}$ \\
\hline Florida Whitewater & 13 & 37 & 12 & 4 \\
Jackie Suthers & 23 & 29 & 15 & 9 \\
Pink Gem & 18 & 40 & 12 & 8 \\
White Wing & 25 & 23 & 16 & 9 \\
LSD $(a=0.05)$ & 4 & 7 & 2 & 2 \\
\hline \hline
\end{tabular}

